\title{
SPATIAL AND STRUCTURAL CHANGES OF THE TOURISM OF HUNGARY FROM THE CHANGE OF THE REGIME TILL PRESENT
}

\author{
János Csapó, Antal Aubert
}

\begin{abstract}
In our study we aim to thoroughly discuss the spatial and structural changes of the tourism of Hungary from the change of the regime till present. As 25 years passed by, since the change of the regime numerous new and challenging processes have been experienced and were affecting the tourism of Hungary where the tourism industry plays a primarily important role both from economic and social perspective. In the first stage of this transformation the country had to face with the problems of the appearance of the market economy, than the joining of the EU became the most important priority and after 2004 some new and modern trends and tendencies began to affect the country's tourism industry which we intend to thoroughly discuss in this paper.
\end{abstract}

Keywords: change of the regime, Hungary, spatial change, structural change, tourism policy

\section{Introduction}

In Hungary, tourism is one of the most important industries of the economy. The direct contribution of tourism to GDP, the ratio of employment in the sector or the government expenditures and focus on tourism, each demonstrate a remarkable (and usually higher) level compared to the averages of the European Union and Central and Eastern Europe as well.

Calculations of the World Travel and Tourism Council indicate that the contribution of tourism to economic performance reached $4.1 \%$ in 2013, and taking into account the multiplier effect, the GDP's (indirect) share of the sector reached $10.6 \%$ in Hungary (2013). A total of 227.5 thousand people, corresponding to $5.8 \%$ of total employment, worked directly in the sector, which - taking also into consideration the multiplier effect - from the indirect perspective can be enhanced to 394.5 thousand $(10.0 \%)$ (WTTC, 2014).

Based on these and the numerous spatial and structural changes that were experienced in tourism the article will discuss the past 25 years of transformation starting from the beginning of the 1990s till present times.

\section{The spatial and timely alteration of the tourism demand}

The 1990s meant a transitional period to Hungary's tourism as well. Besides 
the political-economic-social changes numerous external - uncontrollable and unimpressionable - events expounded its effects. Among these we find such which was predominating nationally, but such effects as well which were experienced on the regional level. So for example those "friendly", former socialist countries which earlier were secluded could appear as new, undiscovered destinations with the change of the regime where the incompletion of the infrastructure was effaced by their novelty to the guests of the western world. In this situation the interest to Hungary has decreased and so the East-Central-European area became an open region for competition where the competitiveness of Hungary declined year by year.

In 1990 Hungary was $5^{\text {th }}$ in the list of the most visited countries of the world, while this rank turned to $7^{\text {th }}$ in $1995,13^{\text {th }}$ in 2002 and $23^{\text {rd }}$ in 2011 . In the meanwhile the share of the country's tourism industry compared to the global market decreased from 4.5\% to 2-2.2\% (Magyar Turizmus Rt., 2003) and in 2013 to $3.1 \%$ (UNWTO, 2014a). On the other hand, taking into consideration the receipts, the country possessed much worse positions between rank 30-40 having the $42^{\text {nd }}$ place in 2010 (Lengyel, 1997, UNWTO, 2014b).

The number of international tourist arrivals was around 20 million until the middle of the 1990s (Magyar Turizmus Rt., 2003) then started to decrease and in the years following 2000 it was stabilised around 15-17 million persons (Figure 1).

Figure 1: The formation of the number of international tourists to Hungary (19902013)

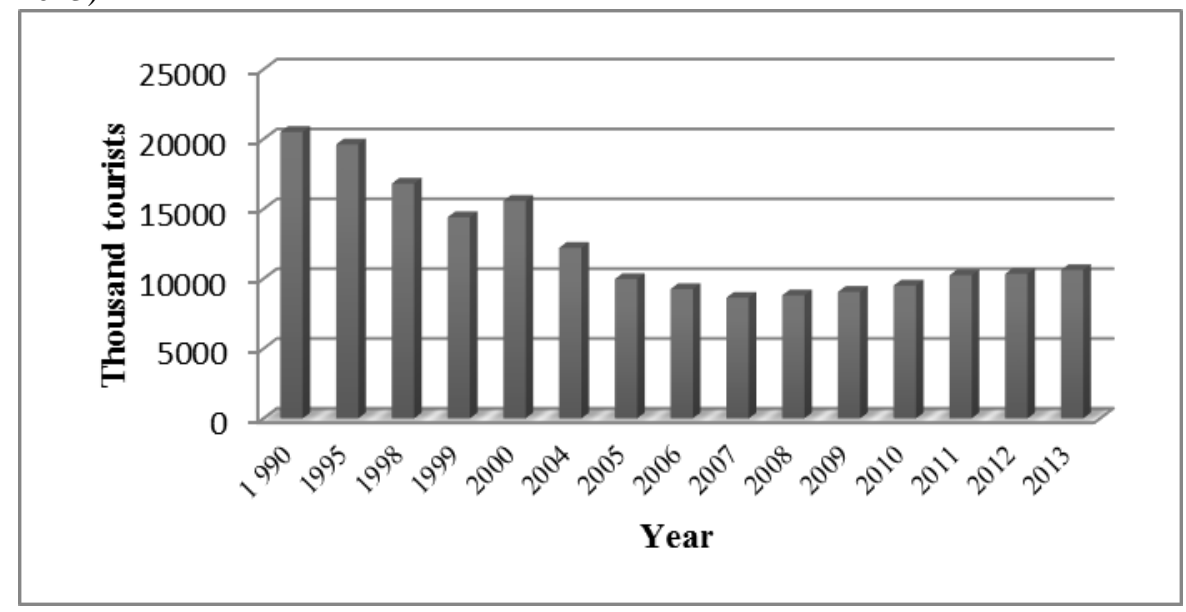

Source: own editing

Among the reasons of the decrease, besides the formerly mentioned weakening of the "peculiarity" effect, we should highlight the role of the outbreak 
of the Balkan civil war which was performing strong regional effects especially in the southern aeras. The most intense decrease of the foreign guests was experienced in South Transdanubia and in Southern Great Plains which are geographically situated the closest to the mentioned region. Neither the relatively high number of visitors can generate an adequate tourist flow and receipts since the number of visitors is roughly two times more than the guest flow in any seasons, which demonstrates the mass presence of transit visitors.

Taking into consideration the tourism of every developed country, the domestic guests provide the basics, so Hungary was made extremely consigned when the domestic tourism collapsed in the 1990s. 1991 was the touch bottom when the ratio of the foreign guest was $67.9 \%$ and the guest nights were $76 \%$. In the following years domestic tourism grew slowly but surely but the real breakthrough was provided by the introduction of the so called recreation cheque. The system, introduced in 1998, became popular from 2003 as it was to be given without tax and duties up to the limit of the all-time minimum wage. Its turnover increasing effect was experienced in every region as well as concerning numerous players of the tourism sector. That is why the planned modification of the system due to the 2008/2009 economic crisis - caused fierce reactions. Finally the professional lobby could achieve a temporary solution but the effects of the modifications are doubtful and unpredictable.

Based on the data base of the CSO (Central Statistical Office) in the past decade the ratio of the domestic tourists concerning all the tourist flow reaches $55 \%$, which shows a faster dynamics of increase since 2000 (domestic: $+40 \%$, foreign $+17 \%)$. From 2002 continuously the domestic guests are in majority in the commercial accommodations. However behind the national average there are significant regional differences. The most attractive destination of the foreign guests visiting Hungary is the central region, where concentration did not even decrease, but increased in the past years (KSH, 2009). The following Figure 2 also demonstrates that taking into consideration the foreign guest flow, besides the Central Hungarian region, the Transdanubian regions play a highlighted role. Nevertheless the concentration of the incoming tourist flow is well characterised by the fact that by 2005 - with the exception of the Central Hungarian Region - in every region the domestic guest nights were in majority, yet in the national aggregate this change is to be experienced only in 2008.

The change of the composition of the foreign guests is a further characteristic process with a powerful effect of Hungary's tourism. The alteration of the earlier structures is changing since the 1990s, besides the classical guest flow the number of visitors from new sending destinations exceeds 100000 guest nights as well, which number we handle as a threshold limit from the point of view of domestic tourism. The foreign visitors to Hungary are concentrated spatially to Budapest so in this respect as well centrality characterises the country. 
Figure 2: Points of intersection of the ratio of international/domestic nights in Hungary

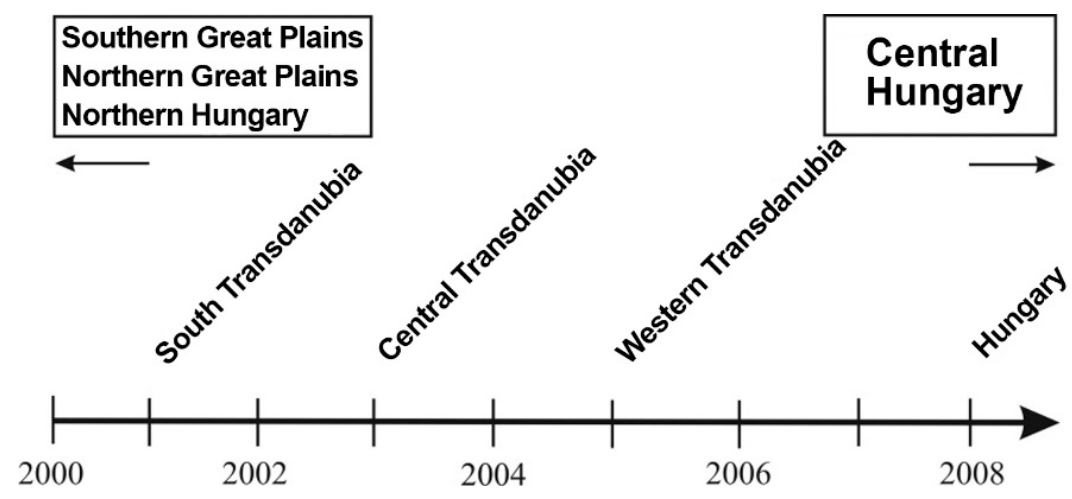

Source: Based on CSO data edited by Berki, 2009

Correspondingly to the past decades, further on the most important deficiency of the domestic tourism is the low level of specified spending. This phenomenon can be explained with numerous reasons, as for example with the exception of quality products, but also the restructuring of the foreign guests show unfavourable conditions as well. It is characteristic in numerous regions today that the number of visitors is stagnating or show only a slight increase, but - based on the gentilitial composition - there are significant regional alterations and changing trends to be identified.

The decrease of the well-paying German guests is questionable in certain regions whether how and in what extent they could be substituted by the quickening east-central-European guests. By today, with the exception of Central Hungary, we find one or more East-Central-European countries among the top three sending destinations to the given region. This change is the most picturesque in the Northern Hungarian region, where - concerning 2008 guest flow data - the Polish guests, being the first in the list, spend two times more guest nights than the Germans.

Only in a small extent but the geographical allocation of the regions influences the composition of the guests. The gentilitial composition of the guests arriving to Budapest basically differs from the national data and is to be considered as unique as well. Besides the German guests, being in the first place, we find such nations - USA, United Kingdom, Italy, Spain - which have a much lower presence in the other regions by number and ratio as well (Figure 3). So, for instance, $90 \%$ of the guests from the USA, United Kingdom and Spain concentrate to Budapest (KSH, 2009). 
Figure 3: The ratio of the foreign guests (\%) and the most important sending countries to the tourism regions of Hungary (2012)

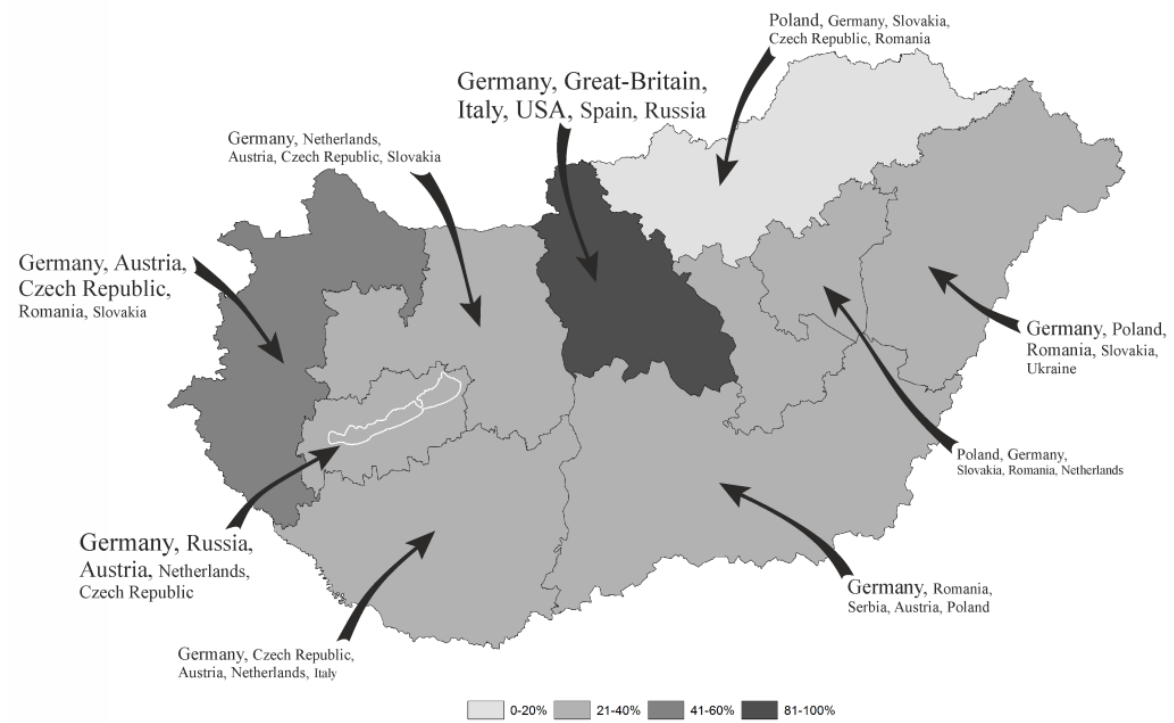

Hungary $>400.001$ Hungary $200.001-400.000$ Hungary $100.001-200.000$ Hungary $50.001-100.000$ Hungary $10.001-50.000$ Hungary $<10.000$ Source: Based on KSH (CSO) ed. by Józsa, 2014

We have to take into consideration the supply characteristics and the trends that can be forecasted during the programming and application system of tourism and during the investment decision as well. Thus for instance it is a warning sign, that nevertheless the quality accommodation capacity - 4 star hotels - grew in the South Transdanubian region, yet in the case of foreign guests their number decreased. It raises the attention to that the capacity widening and quality developments are not enough per se to increase the foreign - and also in an increasing measure the domestic - guest flow (KSH, 2009). During the planning of the hotel investments and the return calculations, we have to take into consideration other influencing factors as well.

\section{The spatial and timely alteration of the tourism supply}

The change of the regime brought alteration to the tourism supply of Hungary as well, but it was as significant as concerning the effect on tourism demand. One of its most important elements was dealing with the accommodations. With the disintegration of the system of social tourism, the owner change of the former state companies, the closure of the companies or 
possibly with their profile settling in most cases the company holiday homes were sold as well. The fast capacity increase of the one and two star hotels and the further low standard accommodations can be interpreted with this process. But there were no significant accommodation developments in the 1990s, it was the era of the depleting of the former tourism infrastructure. Correspondingly to the accommodations, the attraction development was not characteristic as well. Concerning tourism infrastructure shopping tourism became an exception on which significant capacities - commercial centres - were built mainly in bordering areas with local governmental support and finance. But with the rollback of shopping tourism these institutions' reason for existence became queried, in many cases no adequate function was found to these institutions even to present days.

Privatisation soon appeared in the tourism sector, even in 1989 for the development and acquisition of the domestic hotel chain Hungar Hotels they tried to make a privatisation attempt to secure the necessary capital. The first privatisation programme was launched in 1990 when the most well performing state companies - hotel chains such as Danubius - were assigned. The second wave of privatisation started in 1995 by announcing another two hotel chains. By the successful privatisation, the renewal of the concerned hotels occurred as well, than from 1999 another hotel building process has started which is still maintained by the support programmes. In the beginning the hotel constructions concentrated on Budapest and some other accentuated tourism settlements. The applications and accentuated attraction developments announced from 2000 further actuate the quality accommodation developments. In the decade following the change of the regime the foreign working capital appeared in Hungary in a much higher ratio than in any other post socialist countries, but in the subsequent years an equalisation process has been running its course (Behringer et al., 2002). However apart from the above mentioned accentuated institutions, spontaneous and contingent privatisation has been passing off, so there was no planned time schedule for privatisation, which also affected negatively the functioning of the market.

The coordinated development of the tourism supply started with the creation of tendering systems from the 2000s on. The developments of the previous era were realised without state incentives in the framework of private or local governmental investments. The unplanned, spontaneous investments were characteristic in the tourism centres so namely mainly in Budapest and Lake Balaton and in some highlighted health tourism settlements. But it was not accompanied by any sensible results on the national level so concerning guest flow and receipts they remained spot-like developments.

Hungary's joining of the EU multiplied the sources appropriated to tourism. Besides the NHDP (New Hungary Development Plan) the NHRDP (New Hungary Regional Development Plan) and the accentuated projects supported the increase and development of the branch. The basis for distribution of supports is provided 
by the NUTS II regional system, on which' imperfections attention already was raised - providing also a resolving alternative - by the system of the tourism regions created in 1998. However this impoundment could not be validated, although its created institutional system - however with only a few licences - still functions up to present days.

\section{Conclusion}

In a moderately developed economy tourism proved to be a regional development factor in other words an active player of regional policy and so it can be placed perfectly in the objective system of regional policy as well. It has a role in the closing up of lagging regions but at the same time taking into consideration the present trends of tourism the great scale projects satisfy the priorities of a given settlement or pole as well (health tourism, conference tourism, fair and incentive tourism).

Recognising this, the Hungarian regional policy from the $1^{\text {st }}$ Széchenyi Plan (1998-2002) to the 1st and 2nd National Development Plans (2004-2006, 20072013) and the New Széchenyi Plan (2010-) raised tourism to the all-time priorities and it started to appear among the sectoral priorities of the planning periods since 1998.

However, these development programmes concentrated on tourism development, we have to say that the already mentioned structural problems of the tourism industry have not yet been solved.

\section{References}

AUBERT, A. - BERKI, M. 2007. A nemzetközi és a hazai turizmus területi folyamatai, piaci tendenciái a globalizáció korában. Földrajzi Közlemények 55 3. pp. 119-131.

BEHRINGER, ZS. - INDRA D. - KISS K. - VESZELKA K. 2002. A külföldi müködötöke szerepe Magyarország turizmusának fejlödésében a rendszerváltás után. In: Turizmus Bulletin, 6/1 pp.48-55.

KSH (Central statistical Office) database. Available at: www.ksh.hu

LENGYEL, M. 1997. A turizmus versenyképességét befolyásoló tényezők. Mühelytanulmányok 16. - Budapesti Közgazdaságtudományi Egyetem, 61 p.

LENGYEL, M. 2004. A turizmus általános elmélete. Budapest, 2004525 p.

MAGYAR TURIZMUS RT. 2002. Turizmus Magyarországon 1990-2002. Available at: http://neta.itthon.hu/szakmai-oldalak/letoltesek/turizmusmagyarorszagon $114 \mathrm{p}$.

UNWTO 2014a. Tourism Highlights 2014. Available at: http://www.eunwto.org/content/r13521/fulltext.pdf 16 p. 
UNWTO 2014b. World Tourism Barometer - Statistical Annex. Available at: http://www.e-unwto.org/content/w83w37 24 p.

WORLD TRAVEL AND TOURISM COUNCIL 2014. Travel \& Tourism Economic impact 2014 Hungary. World Travel and Tourism Council, London, $24 \mathrm{p}$.

Dr. habil János Csapó, PhD., Dr. habil Antal Aubert, CSc.

Department of Tourism, Faculty of Central European Studies

Constantine the Philosopher University in Nitra

Drážovská 4, 94974 Nitra, Slovakia

E-mail: jcsapo@ukf.sk, aaubert@ukf.sk 